\title{
Workplace bullying: A perspective from the Job Demands-Resources model
}

\author{
Authors: \\ Anja van den Broeck ${ }^{1,2}$ \\ Elfi Baillien ${ }^{1,2}$ \\ Hans De Witte ${ }^{2}$ \\ Affiliations: \\ ${ }^{1}$ Faculty of Economy and \\ Management, HUBrussel, \\ Belgium \\ ${ }^{2}$ Research Group Work, \\ Organisational and \\ Personnel Psychology, K.U. \\ Leuven, Belgium \\ Correspondence to: \\ Anja Van den Broeck \\ Email: \\ anja.vandenbroeck@ \\ hubrussel.be \\ Postal address: \\ Stormstraat 2, 1000 \\ Brussel, Belgium \\ Dates: \\ Received: 30 Nov. 2009 \\ Accepted: 01 Dec. 2010 \\ Published: 23 May 2011 \\ How to cite this article: \\ Van den Broeck, A., \\ Baillien, E., \& De Witte, $H$. \\ (2011). Workplace bullying \\ A perspective from the \\ Job Demands-Resources \\ model. SA Journal of \\ Industrial Psychology/SA \\ Tydskrif vir Bedryfsielkunde, \\ 37(2),Art. \#879, 12 pages. \\ doi:10.4102/sajip.v37i2.879 \\ Note: \\ Anja Van den Broeck and \\ Elfi Baillien contributed \\ equally to this article. The \\ order of the authors was \\ randomly determined.
}

(C) 2011. The Authors. Licensee: OpenJournals Publishing. This work is licensed under the Creative Commons Attribution License.
Orientation: Workplace bullying is characterised as a counterproductive interpersonal behaviour, yielding severe consequences for both the individual and the organisation. The occurrence of workplace bullying is often attributed to a stressful work environment.

Research purpose: The purpose of the study was to test the work environment hypothesis by applying the Job Demands-Resources model to workplace bullying. We expected job demands and job resources to relate to both perpetrators' and actors' reports of workplace bullying.

Motivation for the study: We aimed to extend the outcomes examined in the Job DemandsResources model to a specific form of counterproductive interpersonal behaviour, namely workplace bullying. From the point of view of the literature on bullying, we aimed to substantiate the well-known work environment hypothesis with empirical data.

Research design, approach and method: We applied structural equation modelling on questionnaire data of a large heterogeneous sample of Flemish employees $(N=749)$.

Main findings: Job demands and job resources interacted in the prediction of perpetrators' reports of bullying: job demands associated positively to perpetrators' reports of bullying particularly under the condition of high job resources. Job demands related positively to targets' reports of bullying, while job resources related negatively. These associations were (partially) mediated by emotional exhaustion.

Practical/managerial implications: These results suggest that workplace bullying may indeed be reduced by good job design, that is, by limiting the job demands and increasing job resources. Particular prevention plans may be developed for exhausted employees, as they are vulnerable to workplace bullying, in terms of both becoming perpetrators and victims.

Contribution/value-add: This study attests to the predictive validity of the JD-R model for perpetrators' and targets' reports of workplace bullying. The findings also underline the complex and multi-causal nature of workplace bullying.

\section{Introduction}

Recently, an exponential increase of publications has focussed on the Job Demands-Resources model (JD-R model; Bakker \& Demerouti, 2007). The JD-R model examines the impact of job characteristics (i.e. job demands and job resources) on workers' impaired (i.e. burnout) and optimal (i.e. work engagement) work-related well-being. To date, the JD-R model has been fruitful in explaining a range of outcomes such as, workers' health and well-being, their attitudes towards the job and their behaviour, amongst others. Therefore, the JD-R model may also be a valuable model to predict the organisations' productivity. The current study aims to add to this line of research by examining the JD-R model's predictive value for a particular form of counterproductive interpersonal behaviour, that is, workplace bullying. Specifically, the current study aims to associate job demands and job resources as detailed in the JD-R model to both the perpetrators' and targets' perspective of workplace bullying (Hoel, Zapf \& Cooper, 2002; Matthiesen \& Einarsen, 2007).

Reasons for introducing workplace bullying as a possible outcome in the JD-R model are twofold. In view of the JD-R model, to date, a limited number of studies have focussed on counterproductive and/or interpersonal behaviour at work. Yet, over the last decade, organisations have gradually shifted towards jobs in which workers are increasingly interdependent (Grant \& Parker, 2009). Consequently, it may be valuable to know whether well-established frameworks, such as the JD-R model, may be successful in understanding (counterproductive) interpersonal behaviour (Hoel 
et al., 2002). Of particular resonance may then be workplace bullying, which is an indicator of counterproductive interpersonal behaviour at work (Zapf \& Einarsen, 2003). Workplace bullying has attracted a growing body of scholarly attention (Einarsen, Matthiesen \& Hauge, 2009) and has been linked to substantial implications for both the employees and the organisation involved (Hoel et al., 2002).

In view of workplace bullying, the literature may clearly benefit from a JD-R approach as perpetrators' and targets' reports of bullying have been associated with a range of job characteristics such as workload and autonomy (Hauge, Skogstad \& Einarsen, 2007; Notelaers, De Witte \& Einarsen, 2010) as well as with work-related strain (Baillien, Neyens, De Witte \& De Cuyper, 2009; Bowling \& Beehr, 2006). Firstly, the JD-R model may advance this line of research by modelling the fairly cluttered plethora of job characteristics sampled in previous research. Secondly, the JD-R model may furthermore substantiate from a theoretical point of view how these job characteristics may lead to perpetrators' and targets' reports of bullying through strain.

\section{The Job-Demands Resources model}

The JD-R model expands earlier stress models such as the Job Demand Control Model (Karasek, 1979) and the Effort Reward Imbalance Model (Siegrist, 1996). It assumes that a broad set of job characteristics (categorised as job demands or job resources) may influence work related well-being, which in turn relates to individual and organisational outcomes. Job demands (e.g. workload and role conflict) are those aspects of the work context that tax workers' personal capacities. By wearing out workers' energy, job demands associate with psychological and/or physiological costs, such as strain and burnout (Bakker \& Demerouti, 2007). Job demands are therefore said to elicit an energy depleting process. Job resources (e.g. social support and task autonomy) are those aspects of the work context that (Bakker \& Demerouti, 2007):

1. reduce job demands and their health-impairing impact

2. are functional in achieving work goals

3. stimulate personal growth, development and learning.

As frequently shown in literature on burnout (Halbesleben \& Buckley, 2004), job resources may decrease burnout (Schaufeli \& Bakker, 2004). They may thus further intervene in the energetic process. However, they are also motivational in nature and therefore enhance work engagement (Bakker \& Demerouti, 2007), which is characterised as the complement of burnout (González-Romá, Schaufeli, Bakker \& Lloret, 2006).

Apart from their main effects, job demands and job resources may also interact. On the one hand, job resources may buffer the health-impairing impact of job demands (Bakker \& Demerouti, 2007) to such an extent that workers experiencing high job demands may feel less burned out if they dispose of various job resources; this assumption builds on the Job Demand Control model (Karasek, 1979). Yet, whereas the Job Demand Control model is mainly restricted to time demands, workload, autonomy and, later, social support, the JD-R model advocates that a broad range of job resources may buffer the impact of various job demands. On the other hand, the JD-R model assumes that job demands may boost the health-enhancing effect of job resources (Bakker \& Demerouti, 2007); workers may increasingly benefit from job resources when working under demanding conditions (cf. Hobfoll, 2002).

Numerous studies have supported the assumptions of the JD-R model from both a cross-sectional and longitudinal perspective and when examining the impact of job demands and resources that are only found in specific jobs (e.g. customer contacts, violence) as well as across various jobs (e.g. workload and role problems; Bakker \& Demerouti, 2007). These studies applied the JD-R model to a diverse set of outcomes. Firstly, job demands, job resources, burnout and work engagement have successfully been used to gain insight into workers' well-being and health, including psychosomatic complaints (Hakanen, Bakker \& Schaufeli, 2006) and depression (Hakanen, Schaufeli \& Ahola, 2008; Martinussen, Richardsen \& Burke, 2007). Secondly, the JD-R model has been applied to work-related attitudes such as organisational commitment (Hakanen et al., 2008; Llorens, Bakker, Schaufeli \& Salanova, 2006), job satisfaction (Martinussen et al., 2007) and turnover-intentions (Bakker, Demerouti \& Schaufeli, 2003). Finally, some studies paid attention to workers' absenteeism (Bakker, Demerouti, de Boer \& Schaufeli, 2003; Schaufeli \& Bakker, 2004) and cooperative behaviour, including in-role performance (Bakker, Van Emmerik \& Van Riet, 2008; Salanova, Agut \& Peiró, 2005; Xanthopoulou Bakker, Demerouti \& Schaufeli, 2009) as well as extra-role performance (Bakker, Demerouti \& Verbeke, 2004). These studies indicated that the JD-R model is not only instructive in explaining workers' functioning, but may also be a meaningful framework to understand organisations' productivity.

The current study aims to add to this line of work by examining the JD-R model's benefit in explaining counterproductive interpersonal behaviour at work. Specifically, we aim to investigate the JD-R model's validity for workplace bullying. Herein, we approach workplace bullying from perpetrators' as well as from targets' perspective, which aligns with recent developments in the workplace bullying research domain (Baillien, De Cuyper \& De Witte, in press; De Cuyper, Baillien, \& De Witte, 2009).

\section{Workplace bullying}

Workplace bullying, also labelled as mobbing referring to a group of employees acting negatively towards an employee (Leymann, 1996), as emotional abuse (Keashly, 1998), as victimisation (Aquino \& Thau, 2009) or as harassment (Brodsky, 1976). It refers to a situation in which one or more workers are subjected to negative acts at work. According to the European perspective, workplace bullying is typified as a long-term process (i.e. a minimum of six months) in which minor negative acts accumulate to a pattern of 
systematic maltreatment (Einarsen, 2000; Salin, 2008). These negative acts may concern personal issues (e.g. insults and/or humiliation) as well as work-related issues (e.g. withholding documentation) and social isolation (Cowie, Naylor, Rivers, Smith \& Pereira, 2002). Bullying typically results in a power imbalance between the parties involved; targets often experience problems in defending themselves against the negative acts of perpetrators (Einarsen, Raknes \& Matthiesen, 1994; Einarsen, 2000; Leymann, 1996) and are gradually stigmatised into an inferior position (Einarsen \& Skogstad, 1996; Zapf \& Gross, 2001).

To date, most knowledge of workplace bullying has been developed from targets' experiences and perceptions (Zapf \& Einarsen, 2003). However, much can also be learned from the perpetrators' perspective (Rayner, 1999). Indeed, when wanting to prevent workplace bullying in an adequate way, it takes more than only impacting on factors that may make employees less prone to becoming a target. Interventions that prevent or reduce bullying enactment may be highly necessary. Therefore, the current study aims to examine both perpetrators' and targets' reports of bullying, which aligns with a recent development in the workplace bullying research domain (Baillien et al., in press).

Personal characteristics such as, amongst others, low social competencies or a neurotic personality, may make employees more prone to bullying (Parkins, Fishbein \& Ritchey, 2006; Zapf, 1999). Most studies detailing bullying antecedents were, however, inspired by the work environment hypothesis, which attributes bullying to a stressful work environment (i.e. Einarsen et al., 2009; Notelaers et al., 2010). Such studies examined in particular whether various job characteristics may elicit (mainly targets' reports of) workplace bullying. This body of research resulted in an extensive list of job characteristics that may be involved in this process.

Specifically, targets' reports of bullying have been related to job characteristics such as workload (Agervold \& Mikkelsen, 2004; Baillien, Rodriguez-Muñoz, De Witte, Notelaers \& Moreno-Jiménez, in press), cognitive and emotional demands (Notelaers et al. 2010; Zapf, Knorz \& Kulla, 1996), role problems (Hauge et al., 2007; Notelaers et al., in press) and job insecurity (Neyens, Baillien, Notelaers \& De Witte, 2007). Conversely, job aspects such as autonomy (Baillien, De Cuyper et al., in press; Hubert, Furda \& Steensma, 2001), skill utilisation (Einarsen et al., 1994; Notelaers et al., 2010) and social support (Neyens et al., 2007; Zapf et al., 1996) have been negatively related to targets' reports of workplace bullying.

In addition, recent studies convincingly showed that job characteristics such as job insecurity, workload and autonomy may explain perpetrators' reports of bullying too (Baillien, De Cuyper et al., in press; De Cuyper et al., 2009). Overall, building upon the work environment hypothesis, these studies defined a broad range of job-related antecedents of workplace bullying. However, they, remained rather explorative in nature.
Besides these studies, some authors have started to construct models to explain the emergence of workplace bullying. Baillien and colleagues (2009), for example, developed a Three Way Model. This model describes the processes through which workplace bullying may be triggered. It is grounded in incident based qualitative research and details two processes through which job characteristics may link to perpetrators' as well as targets' reports of bullying ${ }^{1}$. Firstly, poor job characteristics are assumed to pave the way for bullying through interpersonal conflicts (see also Leymann, 1996). Secondly, and perhaps most important in view of the current study, poor job characteristics are expected to elicit work-related strain. Strain may, in turn, lead to perpetrators' and targets' reports of workplace bullying. Specifically, from the perpetrator's perspective, poor job characteristics may elicit negative affect and strain, which may be relieved by directing negative acts towards a co-worker. A similar process has been described in the Revised Frustration Aggression Theory (Berkowitz, 1989) and General Strain Theory (Hinduja, 2007). From the target's perspective, exposure to poor job characteristics may trigger feelings of helplessness, which may lead the employee to violate work-related habits and expectations. Co-workers may then respond to this situation by acting negatively to their colleague, which in the end may escalate into bullying. The employee may therefore become a target of bullying (see also Felson \& Tedeschi, 1993). Similarly, poor job characteristics may wear out the employee's resources. The particular employee then becomes an 'easy target' who offers little resistance against workplace bullying (De Cuyper et al., 2009; Hoel \& Salin, 2003).

The Three Way Model has been valuable in providing possible processes from which perpetrators' and targets' reports of bullying may develop. To date, however, this model has not been empirically tested; probably because of its heuristic nature.

\section{The JD-R model and workplace bullying}

The present study aims to introduce workplace bullying, both from the perspective of perpetrators and targets, as new outcomes in the JD-R model. Research detailing bullying antecedents has on the one hand produced a long list of job characteristics that may be linked to workplace bullying. On the other hand, a model was developed suggesting that job characteristics may lead to (perpetrators' and targets' reports of) workplace bullying via a process of work-related strain (Baillien et al., 2009). In our view, the JD-R model may bridge the two traditions in the bullying literature in two ways.

Firstly, the JD-R provides a sound theoretical model that may structure the long and broad list of job characteristics that (according to the bullying literature) are involved in

1.Besides two process through which job characteristics may give rise to workplace bullying, the Three Way Model also describes a third route through which bullying may emerge; a route that is not related to job characteristics. Specifically, this third may emerge; a route that is not related to job characteristics. Specifically, this third of gossip or a highly competitive climate, may encourage employees to engage in workplace bullying. 
the emergence of workplace bullying. Specifically, the JD-R model allows specifying the content of poor job characteristics in terms of both the presence of job demands and the absence of job resources. As elaborated in the Three Way Model, we expect these job characteristics to trigger both perpetrators' and targets' reports of bullying. Following the principles of the JD-R model, we then expect job demands to associate positively and job resources to associate negatively with perpetrators' and targets' reports of bullying. Moreover, based on the JD-R model, we expect job demands and job resources to interact. According to the JD-R model, job resources may reduce the burden that job demands place on employees. Therefore, we also expect them to reduce the potential negative relationship between job demands and both perpetrators' and targets' reports of workplace bullying.

In sum, we hypothesise as follows:

- Hypothesis 1: Job demands relate positively to perpetrators' reports of bullying (Hypothesis 1a) as well as to targets' reports of bullying (Hypothesis 1b).

- Hypothesis 2: Job resources relate negatively to perpetrators' reports of bullying (Hypothesis 2a) as well as targets' reports of bullying (Hypothesis $2 b$ ).

- Hypothesis 3: Job demands and job resources interact, so that the relationship between job demands and perpetrators' reports (Hypothesis 3a) and targets' reports (Hypothesis 3b) of bullying are weaker under the condition of high compared to low job resources (i.e. buffer hypothesis).

Secondly, the Three Way model describes work-related strain as one of the main processes linking job characteristics to both perpetrators' and targets' reports of workplace bullying. The JD-R model may further add to this literature as it substantiates the energetic process through which job demands and job resources may lead to outcomes such as workplace bullying. Indeed, the JD-R model details that job demands relate positively and job resources relate negatively to work related strain, mostly operationalised as burnout. Through their influence on psychological strain, job demands and job resources may then associate with other aspects of workers' functioning, herein: the degree to which employees consider themselves as perpetrators and/or targets of workplace bullying. In a similar vein, the JD-R model outlines that job resources may also buffer the negative impact of job demands on strain, which then explains why interaction job demands and job resources may interact in the prediction of workplace bullying. Therefore, we argue that burnout and more specifically emotional exhaustion as its main component (Maslach, Schaufeli \& Leiter, 2001), explains (i.e. mediates) the association between job demands, job resources and perpetrators' and targets' reports of bullying.

Specifically, we hypothesise:

- Hypothesis 4: The association between job demands and perpetrators' reports (Hypothesis 4a) and targets' reports (Hypothesis 4b) of bullying is mediated by emotional exhaustion.
- Hypothesis 5: The association between job resources and perpetrators' reports (Hypothesis 5a) and targets' reports (Hypothesis 5b) of bullying is mediated by emotional exhaustion.

- Hypothesis 6: The association of the interaction between job demands and job resources with perpetrators' reports (Hypothesis 6a) and targets' reports (Hypothesis 6b) of bullying is mediated by emotional exhaustion.

We selected four job demands following both the JD-R model's and workplace bullying research traditions, that is, workload, cognitive demands, emotional demands and role ambiguity. With respect to the JD-R model, these demands have frequently been used to test the energetic process (e.g. Bakker, Demerouti, \& Schaufeli, 2005; Hallberg \& Schaufeli, 2006). With respect to the bullying literature, these demands have been related to targets' reports of workplace bullying (e.g. Hauge et al., 2007; Neyens et al., 2007; Notelaers et al., 2010); and some have also been related to perpetrators' reports of bullying (Baillien, De Cuyper et al., in press; De Cuyper et al., 2009). Similarly, four job resources (task autonomy, skill utilisation, social support from colleagues, and social support from the supervisor) were selected based on the JD-R model's and workplace bullying literature. Firstly, they have frequently been indicated as resourceful job aspects in the realm of the JD-R model (e.g. Bakker et al., 2004; Bakker, Demerouti, Taris, Schaufeli \& Schreurs, 2003). Secondly, they have been associated with a decrease in workplace bullying (e.g. Hauge et al., 2007; Neyens et al., 2007; Notelaers et al., 2010).

\section{Research design Procedure and participants}

To be able to realistically capture the variability in the variables under study (Rousseau \& Fried, 2001), we collected a heterogeneous sample in 17 Flemish organisations during Spring and Summer of 2008. In all organisations, the Human Resource department supported data collection. In three organisations, participants completed an electronic questionnaire sent to their professional e-mail address. In the other organisations, participants filled out a paper and pencil questionnaire. After completion, questionnaires could be posted in a box at the organisation's Human Resource department, from which they were picked up by the researchers ${ }^{2}$.

In total, 965 questionnaires were returned (response rate $43 \%$ ). Complete information were provided by 749 respondents, and included in the sample. As participation was voluntary and anonymous, we did not acquire any information about the non-respondents. The majority of the respondents were female $(67 \%)$. Educational level was rather high: $41 \%$ of the participants obtained a Bachelors' degree and 37\% acquired a Masters' degree. About $11 \%$ of the participants were blue-

2.Controlling for the sampling method did not significantly alter the results. 
collar workers, $14 \%$ were white-collar workers, $50 \%$ were professionals. Most participants occupied a full time position $(77 \%)$ and had a permanent contract (73\%). Mean age of the respondents was 37 years $(\mathrm{SD}=11.01)$.

\section{Measures}

Job demands: Workload was tapped with four items such as 'I have a lot of work to do' (Chronbach's $\alpha=0.90$; Van Veldhoven \& Meijman, 1994). Two items assessed cognitive demands ( $r=0.77$; Van Veldhoven \& Meijman, 1994); an example being 'My job requires a lot of concentration'. Three items such as 'I get conflicting orders' measured role ambiguity (Chronbach's $\alpha=0.78$; Van Veldhoven \& Meijman, 1994). Finally, two items such as 'My job requires me to hide my feelings' measured emotional demands ( $r=0.63$; Kristensen, Hannerz, Hogh \& Borg, 2005). For all items, responses varied on a 5-point Likert scale from 1 (totally disagree) to 5 (totally agree).

Job Resources: Task autonomy was measured using five items such as 'I can plan my own work' (Chronbach's $\alpha=0.75$; Rosenthal, Guest \& Peccei, 1996). Social support from colleagues (Chronbach's $\alpha=0.83$ ) and social support from the supervisor (Chronbach's $\alpha=0.89$ ) were assessed with five items each. Examples were 'My colleagues/ supervisor help(s) me to get the work done' and 'My colleagues/ supervisor appreciate(s) me' (Rigotti, Mohr, De Cuyper, De Witte, Bernhard et al., 2003). Skill utilisation was tapped using four items such as 'My job requires me to learn new things' (Chronbach's $\alpha=0.73$; Van Veldhoven \& Meijman, 1994). For all items, respondents indicated whether or not they endorsed the statement on a 5-point scale ranging from 1 ('totally disagree')to 5 ('totally agree').

Emotional exhaustion was measured with the five items of the Dutch version of the Maslach Burnout Inventory-General Survey ( $\alpha=0.88$; Schaufeli \& Van Dierendonck, 2000). Items such as 'I feel totally exhausted in my job' were answered on a 7-point Likert scale ranging from 0 ('never')to 6 ('always').

Workplace bullying was measured with the 9-item Short Negative Acts Questionnaire for targets (Chronbach's $\alpha$ $=0.85$; Notelaers \& Einarsen, 2008) as well as perpetrators (Chronbach's $\alpha=0.82$; De Cuyper et al., 2009). This questionnaire describes personal (e.g. gossiping) and as well as work-related (e.g. being withheld information) negative acts that may be considered as bullying when occurring on a regular basis. Respondents indicated how often they were exposed to (to measure to what extend one is a target) and performed (to measure to what extent one is a perpetrator) each act during the last six months on a 5-point frequency scale ranging from 1 ('never') to 5 ('daily'). In line with literature on bullying, all items for bullying exposure and enactment were included in their respective scales (Nielsen, Skogstad, Matthiesen, Glaso, Aasland et al., 2009).

\section{Plan of analysis}

The hypotheses were examined through Structural Equitation Modeling (SEM) using the maximum-likelihood method in LISREL 8.72 (Jöreskog \& Sörbom, 2004). To be able to also test the job demands-job resources interaction, we followed the procedure of Mathieu, Tannenbaum and Salas (1992) as outlined by Cortina, Chen and Dunlap (2001; see also Bakker, Hakanen, Demerouti \& Xanthopoulou, 2007, for a similar approach in the realm of the JD-R model). Specifically, the independent variables (i.e. job demands, job resources and the job demands-job resources interaction) were represented by one indicator: their standard scale score. For example, the indicator of the latent job demands-job resources variable was the product of the standardised manifest variables for job demands and job resources. The mediating variable (i.e. emotional exhaustion) as well as the dependent variables (i.e. perpetrators' and targets' reports of workplace bullying) were represented by their respective items. In line with earlier observations that perpetrators' reports may associate with targets' reports of bullying and vice versa, both factors were allowed to correlate (De Cuyper et al., 2009). Significant job demands-job resources interactions were further analysed using simple slope analyses (Meier, 2008).

As data screening using Prelis 2.72 (Jöreskog \& Sörbom, 2004) revealed data non-normality at univariate and multivariate level, in addition to the covariance matrix, the asymptotic covariance matrix was used and the Satorra-Bentler Scaled Chi-square (SBS- $\chi^{2}$; Satorra \& Bentler, 1994) was inspected. Model fit was evaluated using three goodness of fit indices (Hu and Bentler, 1999):

- the Root Means Square Error of Approximation (RSMEA)

- the Comparative Fit Index (CFI)

- the Standardised Root Means Square Residuals (SRMR).

CFI values larger than 0.95 indicate excellent fit; values larger than 0.90 indicate good fit (Holye, 1995; Bentler, 1990). RSMEA below 0.05 in combination with SRMR values below 0.09 indicate excellent fit, whereas values below 0.08 and 0.10, respectively, indicate good fit (Byrne, 2001). The mediating role of emotional exhaustion was examined following Holmbeck (1997) (see also Van den Broeck, Vansteenkiste, De Witte \& Lens, 2008). Firstly, we tested in the direct model whether job demands, job resources and the interaction-term related to perpetrators' as well as targets' reports of workplace bullying. Second, we examined the full mediation model in which job demands, job resources and the job demands-job resources interaction-term associated with emotional exhaustion, which, in turn, was related to both aspects of workplace bullying. Then, we computed multiple partial mediation models in which we additionally allowed direct relationships between the job characteristics and perpetrators' and targets' reports of workplace bullying. We examined whether these models showed improved fit compared to the full mediation model using chi-square difference tests. Before testing the hypotheses, the measurement model was evaluated using confirmatory factor analysis (CFA). 


\section{Results}

\section{Preliminary analysis}

Measurement model

Firstly, we tested the divergent validity of the latent factors by computing three different models. As prescribed by Harman (1979), the first model was a null model, in which all items loaded on one factor. The second model was the expected measurement model including all study variables: job demands, job resources, job demands-job resources, emotional exhaustion and perpetrators' and targets' reports of workplace bullying. Finally, in line with Podsakoff, Mackenzie, Lee and Podsakoff (2003), we calculated a third model in which the respective items loaded on both their expected factors as well as on a latent common method factor. The expected measurement model, including 26 observed variables and 6 latent factors, yielded a good fit to the data:

- $\operatorname{SBS}-\chi^{2}(424)=1967.43$

- $p<0.001$

- $\quad$ RSMEA $=0.05$

- $\mathrm{SRMR}=0.07$

- $\mathrm{CFI}=0.95$

It fitted better to the data than the one factor model, $\Delta$ SBS- $\chi^{2}(10)=5678.69 ; p<0.001$. Moreover, the common method factor in the one factor model explained only $13,51 \%$ of the total variance, which is below the $25 \%$ threshold for common method variance observed by Williams, Cote and Buckley (1989). The third model provided yet a better fit to the data than the expected measurement model, $\Delta$ SBS- $\chi^{2}(31)$ $=695.97 ; p<0.001$. However, in this model, the common method factor only explained $8.94 \%$ of the total variance. Therefore, it could be concluded that common method variance did not significantly bias the participants' responses (Podsakoff et al., 2003).

\section{Correlation analysis}

Table 1 provides an overview of the correlations between the variables under study. The overall category of job demands did not relate to perpetrators' reports of workplace bullying. In terms of the different job demands, role ambiguity and emotional demands related positively with perpetrators' reports of bullying. Workload was unrelated and cognitive demands were negatively related to bullying enactment. Each of the job demands related positively to targets' reports of bullying. Job resources generally did not relate to perpetrators' reports of workplace bullying. Autonomy forms an exception, as it related positively to perpetrators' reports of bullying. Job resources related negatively to targets' reports of workplace bullying.

In line with the JD-R model, job demands related negatively with job resources and positively with emotional exhaustion; job resources related negatively with emotional exhaustion. Emotional exhaustion related positively with both perpetrators' and targets' reports of workplace bullying. Both perspectives on workplace bullying were positively related.

\section{Primary analysis}

\section{Direct model: Job demands and job resources predicting workplace bullying}

We started with the computation of the direct model in which job demands, job resources and job demands-job resources were related to both perpetrators' and targets' reports of workplace bullying. This model yielded a good fit to the data:

- $\quad \operatorname{SBS}-\chi^{2}(182)=1045.64$

- $p<0.001$

- RSMEA = 0.05

- $\quad$ SRMR $=0.06$

- $\mathrm{CFI}=0.97$.

Contrary to Hypothesis 1a, job demands did not relate to perpetrators' reports of workplace bullying; $\gamma=0.11$, not significant. They related positively to targets' reports of workplace bullying; $\gamma=0.24, p<0.001$, thereby confirming Hypothesis 1b. Job resources showed no significant relationship with perpetrators' reports of workplace bullying; $\gamma=-0.04$, not significant. Hypothesis $2 \mathrm{a}$ was therefore not corroborated. In line with Hypothesis 2b, however, job resources related negatively with targets' reports of workplace bullying; $\gamma=-0.25, p<0.001$. The job demands-job resources interaction was significant for perpetrators' reports of bullying; $\gamma=0.15, p<0.05 .^{3}$ Hypothesis 3a suggests that

3.Follow up exploratory regression analysis revealed that particularly social support interacted with the job demands. Supervisory support interacted with each of the job demands, whilst social support from colloapues interacted with workload and job demands, whilst social support from colleagues interacted with workload and cognitive demands. In addition, task autonomy interacted with both role ambiguity and cognitive demands. These results are available from the corresponding authors
upon request.

TABLE 1: Correlation amongst the study variables.

\begin{tabular}{|c|c|c|c|c|c|c|c|c|c|c|c|c|}
\hline Variables & 1 & 2 & 3 & 4 & 5 & 6 & 7 & 8 & 9 & 10 & 11 & 12 \\
\hline 1. Job demands & - & - & - & - & - & - & - & - & - & - & - & - \\
\hline 2. Workload & $0.73^{* *}$ & - & - & - & - & - & - & - & - & - & - & - \\
\hline 3. Cognitive demands & $0.56 * *$ & $0.38 * *$ & - & - & - & - & - & - & - & - & - & - \\
\hline 4. Role ambiguity & $0.68 * *$ & $0.30 * *$ & 0.06 & - & - & - & - & - & - & - & - & - \\
\hline 5. Emotional demands & $0.69 * *$ & $0.25^{* *}$ & $0.11^{* *}$ & $0.43^{* *}$ & - & - & - & - & - & - & - & - \\
\hline 6. Job resources & $-0.19 * *$ & 0.04 & $0.14 * *$ & $-0.27 * *$ & $-0.38^{* *}$ & - & - & - & - & - & - & - \\
\hline 7. Task autonomy & $-0.21 * *$ & $-0.07 *$ & 0.01 & $-0.17^{* *}$ & $-0.30 * *$ & $0.69 * *$ & - & - & - & - & - & - \\
\hline 8. Colleagues' support & $-0.13^{* *}$ & 0.02 & 0.07 & $-0.20 * *$ & $-0.22 * *$ & $0.66^{* *}$ & $0.20 * *$ & - & - & - & - & - \\
\hline 9. Supervisory support & $-0.34 * *$ & $-0.10 * *$ & -0.03 & $-0.38^{* *}$ & $-0.38^{* *}$ & $0.74 * *$ & $0.30 * *$ & $0.46^{* *}$ & - & - & - & - \\
\hline 10. Skill ulitisation & $0.18^{* *}$ & $0.24 * *$ & $0.33^{* *}$ & 0.05 & $-0.11 * *$ & $0.61^{* *}$ & $0.34 * *$ & $0.18^{* *}$ & $0.15^{* *}$ & - & - & - \\
\hline 11. Emotional exhaustion & $0.36 * *$ & $0.25 * *$ & $0.11^{* *}$ & $0.29 * *$ & $0.27 * *$ & $-0.17 * *$ & $-0.11 * *$ & $-0.10 * *$ & $-0.22 * *$ & 0.01 & - & - \\
\hline 12. Perpetrators' reports of bullying & 0.05 & -0.04 & $-0.10^{* *}$ & $0.18^{* *}$ & $0.07^{*}$ & -0.03 & $0.07^{*}$ & -0.04 & -0.03 & -0.06 & $0.22 * *$ & - \\
\hline 13. Targets' reports of bullying & $0.32 * *$ & $0.12^{* *}$ & -0.02 & $0.43 * *$ & $0.30 * *$ & $-0.31 * *$ & $-0.14 * *$ & $-0.33^{* *}$ & $-0.29 * *$ & $-0.09 *$ & $0.31^{* *}$ & $0.39 * *$ \\
\hline
\end{tabular}

${ }^{*}, p<0.05 ;{ }^{* *}, p<0.01$ 
the impact of job demands on workplace bullying would be buffered by job resources. This hypothesis was not supported. Simple slope analyses for low (i.e. 1 SD below the mean) and high (i.e. $1 \mathrm{SD}$ above the mean) job demands revealed that job demands associated positively with being an perpetrator of workplace bullying particularly under conditions of high (i.e. $1 \mathrm{SD}$ above the mean; $b=0.07, \mathrm{SE}=0.02, t=3.54$, $p<0.001$ ) job resources,. Moreover, job demands were unrelated to being a bully when job resources were low (i.e. $1 \mathrm{SD}$ below the mean; $b=-0.01, \mathrm{SE}=0.01, t=-0.56$, not significant). This interaction is depicted in Figure 1. Contrary to Hypothesis $3 b$, job resources did not moderate the association between job demands and targets' reports of workplace bullying; $y=0.02$, not significant.

\section{Full and partial mediation model}

To test Hypotheses 4, 5 and 6, we subsequently conducted a full mediation model in which emotional exhaustion was expected to fully mediate the relationships from job demands, job resources and job demands-job resources to perpetrators' and target's reports of bullying. This model showed good fit to the data; SBS- $\chi^{2}(293)=1288.58, p<0.001$; RSMEA $=0.05$; $\mathrm{SRMR}=0.06$, and CFI $=0.97$. In line with the JD-R model, job demands related positively to emotional exhaustion; $\gamma=0.37$, $p<0.001$, whereas job resources related negatively; $\gamma=-0.12$, $p<0.01$. Contrary to expectations, the interaction between job demands and job resources was not significantly related to emotional exhaustion; $\gamma=0.00$, not significant. Emotional exhaustion related positively to both perpetrators' and targets' reports of workplace bullying; $\gamma=0.28$ and $\gamma=0.34$, respectively, $p$-values $<0.001$.

We then continued by computing a series of partial mediation models in which we completed the full mediation model with direct relationships between the independent and dependent variables that were significant in the direct model. The following direct relationships resulted in improved model fit:

- from job demands to targets' reports of workplace bullying; $\Delta$ SBS- $\chi^{2}(1)=13.72 ; p<0.001$

- from job resources to targets' reports; $\Delta$ SBS- $\chi^{2}(1)=39.33$; $p<0.001$

- from the job demands-job resources interaction to perpetrators' reports of workplace bullying; $\Delta$ SBS- $\chi^{2}(1)$ $=21.42 ; p<0.001$.

We therefore calculated a final model that included these direct relationships. This model fitted the data well:

- $\operatorname{SBS}-\chi^{2}(291)=1226.93$

- $p<0.001$

- $\quad$ RSMEA $=0.05$

- $\quad \mathrm{SRMR}=0.04$

- $\mathrm{CFI}=0.97$.

As depicted in Figure 2, in this final model, job demands related positively to emotional exhaustion. Job demands also yielded a direct positive association with targets' reports of workplace bullying. Job resources related negatively to emotional exhaustion, but were also negatively related to targets' reports of workplace bullying. The job demands-job

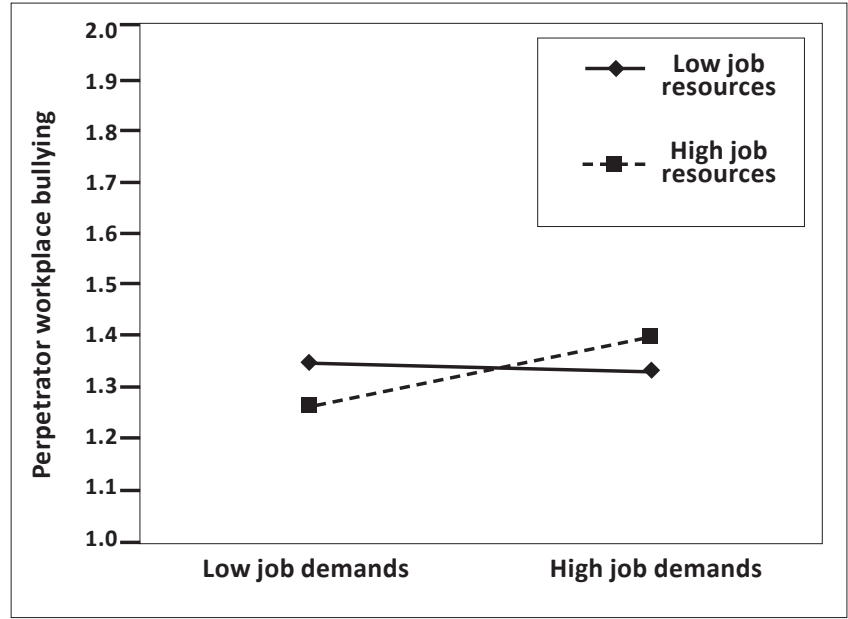

FIGURE 1: Interaction effects of job demands and job resources on perpetrators' reports of workplace bullying.

resources interaction was only related to perpetrators' reports of workplace bullying. Emotional exhaustion was related to both perpetrators' and targets' reports of workplace bullying. Perpetrators' and targets' reports of workplace bullying were positively related.

Finally, we examined more formally the mediational role of emotional exhaustion in the associations of job demands and job resources with workplace bullying through a series of Sobel tests. Sobel tests indicated that emotional exhaustion partially mediated the positive relation of job demands with targets' reports of bullying; $z=0.08, p<0.01$, thereby confirming Hypothesis $4 \mathrm{~b}$. The negative relationship between job resources and targets' reports was also partially mediated by exhaustion; $z=-0.02, p<0.05$. This supports Hypothesis $5 b$.

In sum, no direct associations were found of job demands and job resources with perpetrators' reports of workplace bullying; rejecting Hypotheses $1 \mathrm{a}$ and $2 \mathrm{a}$. Hypotheses $1 \mathrm{~b}$ and $2 \mathrm{~b}$ that the presence of job demands and the lack of job resources associated with targets' reports of workplace bullying were confirmed. The job demands-job resources interaction was significant when predicting perpetrators' reports of bullying. However, whilst we expected that high job resources would buffer the positive association between job demands and bullying perpetration in Hypothesis $3 a$, results showed that particularly the combination of high job demands and high job resources was indicative of perpetrators' reports of bullying. Regarding the explanatory process linking job demands, job resources and workplace bullying (i.e. mediation by emotional exhaustion), results revealed that only the relationships between job demands and targets' reports of bullying and between job resources and targets' reports of bullying were partially mediated by emotional exhaustion. Hypotheses $4 \mathrm{~b}$ and $5 \mathrm{~b}$ were thereby confirmed. As neither job demands nor job resources yielded a direct relation with perpetrators' reports of workplace bullying, no mediation could take place in these relationships. Hypotheses $4 \mathrm{a}$ and 5 a were therefore rejected. The job demands-job resources interaction was unrelated to emotional exhaustion, thereby 


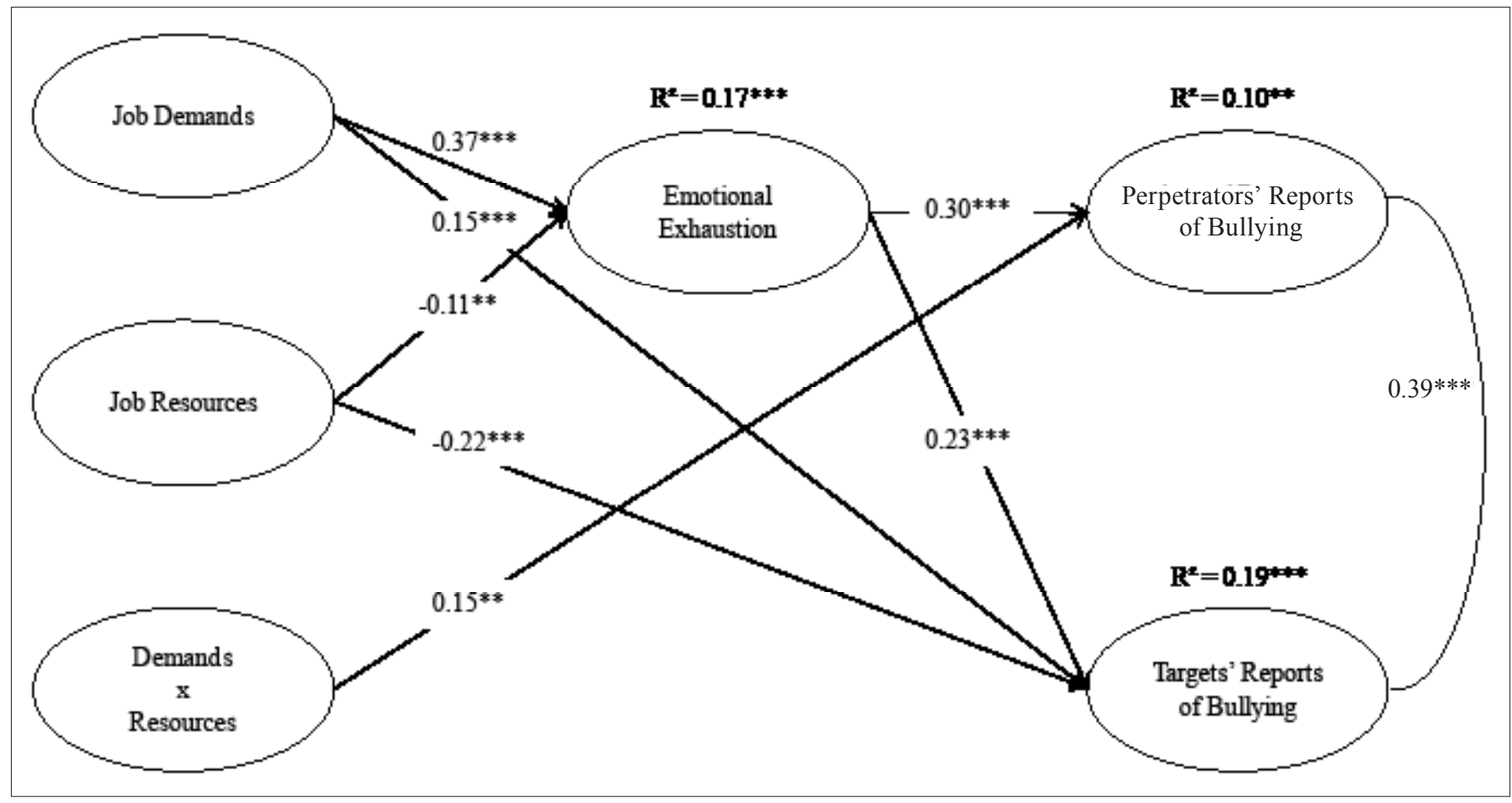

${ }^{* *} p<0.01 ; * * * p<0.001$

FIGURE 2: Emotional exhaustion mediating the associations from job demands and job resources to perpetrators' and targets' reports of workplace bullying.

excluding emotional exhaustion as a potential mediator in its relationship with workplace bullying. Hypothesis 6 was therefore not corroborated.

\section{Discussion}

The current study aimed to expand the JD-R model to perpetrators' and targets' reports of workplace bullying. Such an approach may firstly add to the JD-R model literature. A plethora of studies attested to the JD-R model's predictive validity regarding workers' health and functioning (for an overview; see Bakker \& Demerouti, 2007). However, research on the JD-R model's validity to understand social stress is fairly lacking. As interdependence amongst employees is growing, smoothing the social relationships in the work context may be amongst the most important challenges for organisations to deal with in order to remain effective (Grant \& Parker, 2009). Therefore, the current research aimed to examine whether the JD-R model may be a fruitful approach to understand these phenomena.

Secondly, the current study may advance insights in workplace bullying by introducing the JD-R model as a sound and well-established theoretical model. This study follows the work environment hypothesis (Einarsen et al., 2009; Notelaers et al., 2010), further detailed in the Three Way Model (Baillien et al., 2009). Herein both perpetrators' and targets' reports of bullying are ascribed to job characteristics and psychological strain. These frameworks have generally been tested by exploring the impact of various job characteristics and aspects of work related strain on workplace bullying. The JD-R model may provide a comprehensive framework to group the job characteristics studied this far and allows to define clear hypotheses on how these job characteristics may lead to various aspects of workers' functioning through strain, that is, emotional exhaustion or burnout.

Firstly, the current results largely confirmed the assumptions of the JD-R model and the energetic process in particular: job demands were positively and job resources were negatively related to emotional exhaustion. However, no evidence was found for the association between the job demands-job resources interaction term and emotional exhaustion. Previous research attesting to this interaction, however, largely focused upon the interplay of particular job demands and job resources rather than the general categories (e.g. Hakanen, Bakker \& Demerouti, 2005). These studies established that specific job resources were a stronger buffer for particular job demands than others were. However, to date, it remains unclear which combinations of job demands and job resources may particularly interact. Therefore, we would like to encourage future research to unravel the conditions under which such interactions are most likely to be found to predict emotional exhaustion.

Most important for the current study were, however, the associations of job demands, job resources, and their interaction with workplace bullying (partially through emotional exhaustion). Regarding the perpetrators' perspective, results revealed no relationships between the general categories of job demands, job resources and perpetrators' reports of bullying. Hypotheses 1a and $2 \mathrm{a}$ were thus rejected, thereby also rejecting Hypotheses $4 \mathrm{a}$ and $5 \mathrm{a}$, in terms of the mediational role of emotional exhaustion in these relationships. The correlation analysis may perhaps shed further light on the lack 
of direct relationships of job demands and job resources and perpetrators' reports of workplace bullying.

In terms of job resources, the correlation analysis indicated that only autonomy yielded a significant relation with perpetrators' reports of workplace bullying. Contrary to expectations, this relationship was positive. Regarding job demands, the correlation analysis seems to indicate that particular job demands may yield opposite relationships with perpetrators' reports of bullying: whereas role demands and emotional demands displayed the expected positive relationship, cognitive demands were negatively related to perpetrators' reports of workplace bullying. These results seem to align with the recent differentiation of job demands into 'job hindrances' and 'job challenges'. Whereas job hindrances unambiguously lead to negative consequences, job challenges may have additional beneficial effects (Podsakoff, Lepine \& Lepine, 2007; Van den Broeck, Vansteenkiste, De Cuyper \& De Witte, 2010). Previous research indicated that encountering job hindrances elicit counterproductive behaviour such as arriving late and neglecting instructions on a daily basis. Job challenges relate negatively to such behaviour (Rodell \& Judge, 2009). The current results may suggest that similar associations can be found in view of perpetrators' reports of workplace bullying. Future research is, however, necessary to test further this assumption, for example, by using a larger set of job demands.

Perhaps most importantly in view of the current focus on the JD-R model, the results indicate that job demands and job resources particularly associate with perpetrators' reports of bullying when 'joining forces'. Contrary to the predictions based on the JD-R model (Hypothesis 3a); however, job resources did not buffer the associations of job demands with perpetrators' reports of bullying. To the contrary, job resources appeared to boost the relation of (high) job demands with bullying: whilst job demands were unrelated to workplace bullying when job resources were absent, they related positively to perpetrators' reports of bullying, when job resources were high. One possible explanation for this result could be that job demands may provide the necessity for bullying perpetrators to act out. The presence of job resources may then provide perpetrators' with the possibility to deal with job demands by involving in bullying enactment.

This may hint at yet other processes through which employees may become a perpetrator of bullying. One process suggested in the literature on bullying may then be the emergence and the procession of interpersonal conflicts (Leymann, 1996). Specifically, as elaborated in the second process of the Three Way model (Baillien et al., 2009), poor job characteristics may pave the way for conflicts. Escalated conflicts may, in turn, encourage workplace bullying. The more (formally or informally) powerful employee may then become perpetrator; the powerless employee may become the target. In terms of job demands and job resources, it may be reasonable to assume that job demands may agitate employees, which then serves as a breeding ground for conflicts amongst workers. The availability of high job resources may then grant particular workers with high power, which makes them susceptible to enactment of workplace bullying. The positive association between task autonomy and perpetrators' reports of bullying seems to align with this view. Indeed, employees who can act autonomously in their job might have more freedom to involve in bullying perpetration. De Cuyper and colleagues (2009) also prompted the reasoning that resources may provide the opportunity for bullying in demanding circumstances. These researchers established that employability, as a personal resource, may foster workplace bullying behaviour amongst job insecure employees.

In terms of targets' reports of bullying, job demands displayed the expected positive association, confirming Hypothesis $1 \mathrm{~b}$. Job resources demonstrated the expected positive relation, in line with Hypothesis $2 b$. Thus, demanding work contexts as well as the lack of job resources may make workers vulnerable to becoming a target of workplace bullying. These findings expand previous research in the realm of the JD-R model by indicating that job demands and job resources may not only successfully explain workers' well-being, attitudes and behaviour, but may also explain systematic interpersonal maltreatment.

From a bullying perspective, these results replicate earlier research exploring job characteristics as antecedents of targets' reports of bullying, but also advance the literature on bullying as they meaningfully group the cluttered list of job characteristics into job demands and job resources. In line with the expectations of both the JD-R model and the Three Way Model, emotional exhaustion may partially account for the associations of both categories of job characteristics and targets' reports of workplace bullying (Hypotheses $4 \mathrm{~b}$ and $5 b$ ). These findings further sustain the much cited work environment hypothesis, which links bullying to a stressful work environment (e.g. Einarsen et al., 1999; Notelaers et al., 2010). They also confirm the Three Way model (Baillien et al., 2009) arguing that poor job characteristics lead to targets' reports of bullying through the development of strain.

Contrary to our expectations (Hypothesis $3 b$ ), job demands and job resources did not interact when predicting targets' reports of bullying. Job resources did thus not buffer the negative impact of job demands with regard to targets of bullying. In other words, in contrast to perpetrators' reports of bullying in which job demands and job resources joined forces, both categories of job characteristics are independently associated with targets' reports of bullying in an either-or manner: either the presence of high job demands or the presence of low job resources suffices in view of being a target.

\section{Limitations and practical recommendations}

Some limitations need to be taken into account when interpreting the current results. Firstly, this study relies on self-reports, which might increase the risk of common method variance. As indicated, however, our analyses indicated that such method effects did not significantly influence our results (Podsakoff et al., 2003). This suggests that the precautions to prevent common method variance were effective. Indeed, during data-collection, we underlined that there were no right or wrong answers and guaranteed confidentiality. All these 
measures are assumed to reduce the risk of common method variance (Podsakoff et al., 2003). A related methodological problem could be social desirability, particularly in view of perpetrators' reports of workplace bullying. Our findings may therefore bear on a sub-group of respondents who are willing to admit their negative acts. Social desirability, however, generally results in an underestimation of effects due to a lack of variance. This implies that relationships may become even stronger when accounting for social desirability. Using measures of different sources could have been an effective way to reduce further common method variance and social desirability. Although this might be feasible for job demands and job resources (see for example, Demerouti, Bakker, Nachreiner, \& Schaufeli, 2001), the reliance on employees' perceptions allowed us to capture fully nuances in the degree one experiences workplace bullying, which may be considered as a strength of this study.

Secondly, as the current study relied on cross-sectional data, no conclusions regarding causality can be drawn. However, we relied on theoretical as well as empirical reasons to present job demands and job resources as antecedents of emotional exhaustion and workplace bullying. From a theoretical point of view, the JD-R model conceptualises job demands and job resources as antecedents of work related well-being through which other outcomes emerge (Bakker \& Demerouti, 2007). This causal order has received large empirical support (Hakanen et al., 2008), although some evidence is also found for the reversed causation (e.g. Xanthopoulou et al., 2009). Similarly, the literature on bullying in general and the Three Way model in particular assume that the work environment leads to workplace bullying via strain, rather than the other way around. Some scholars, however, suggest that workplace bullying may also result in psychological strain (Mikkelsen \& Einarsen, 2002; Rodriguez-Munoz, Baillien, De Witte, Moreno-Jiménez \& Pastor, 2009), whilst still others advocate reciprocal relationships (Hoel et al., 2002). Empirically, unreported analyses from the current study, however, indicated that targets' reports of bullying did not mediate the association from job demands and job resources to emotional exhaustion; these results are available upon request. Yet, workplace bullying and psychological strain may nonetheless be closely intertwined. Therefore, we encourage future studies to apply longitudinal or cross-lagged designs to gain further understanding in targets' reports of bullying and to explore the possibility of reversed causation or reciprocal relationships.

Another promising route for future research could be to examine further the processes through which workplace bullying may develop from job characteristics. Previous literature suggested that strain might be amongst the most important processes linking job demands and job resources with both perpetrators' and targets' reports of workplace bullying. Our findings, however, underline that workplace bullying may develop from a complex and multi-causal process (Salin, 2003). Indeed exhaustion did not fully account for the association between job demands, job resources, their interaction and both perspectives on workplace bullying. Future research might therefore examine whether, for example, work engagement may also play a role, as outlined in the motivational process of the JD-R model. In such cases, the lack of job resources might harm workers' enthusiasm. Less enthusiastic workers may then show less commitment to their work (Hakanen et al., 2008) and invest less in extra role behaviour (Bakker, Demerouti \& Verbeke, 2004). Such behaviour might, in turn, isolate the particular workers from their more enthusiastic colleagues, resulting in neglect and, eventually, in becoming a target of bullying.

Despite these limitations, from a practical point of view, the current results may assist practitioners in facilitating the good social relationships amongst workers. Specifically, the results suggest that, in general, workplace bullying may be reduced by limiting job demands and increasing job resources. Particular attention may be paid to employees who feel exhausted, as they either run increased risk to become perpetrators' or targets of workplace bullying.

\section{Conclusion}

The current study demonstrates that the JD-R model may be a fruitful approach to understand the growing interdependence amongst workers in general (Grant \& Parker, 2009) and perpetrators' and targets' reports of workplace bullying in particular. The JD-R model furthermore closes the gap between the theoretical assumptions and empirical findings in the bullying domain suggesting that job characteristics may elicit workplace bullying trough job strain. The results largely support this assumption. Yet, at the same time, the current study's findings underline that workplace bullying is a multi-causal phenomenon, which deserves further research attention.

\section{References}

Agervold, M., \& Mikkelsen, E.G. (2004). Relationships between bullying, psychosocia work environment and individual stress reactions. Work and Stress, 18, 336-351. doi:10.1080/02678370412331319794

Aquino, K., \& Thau, S. (2009). Workplace victimization: Aggression from the targets perspective. Annual Review of Psychology, 60, 717-741. doi:10.1146/annurev. psych.60.110707.163703, PMid:19035831

Baillien, E., De Cuyper, N., \& De Witte, H. (in press). Job autonomy and workload as antecedents of workplace bullying: A two-wave test of Karasek's Job Demand Control Model for targets and Perpetrators. Journal of Occupational and Organizational Psychology.

Baillien, E., Neyens, I., De Witte, H., \& De Cuyper, N. (2009). Towards a three way model of workplace bullying: a qualitative study. Journal of Community and Applied Social Psychology, 19, 1-16. doi:10.1002/casp.977

Baillien, E., Rodriguez-Muñoz, A., De Witte, H., Notelaers, G., \& Moreno-Jiménez, B. (in press). The Demand-Control Model and targets' reports of bullying at work: A test within Spanish and Belgian blue-collar workers. European Journal of Work and Organisational Psychology.

Bakker, A.B., \& Demerouti, E., (2007). The Job Demands-Resources model: state of the art. Journal of Managerial Psychology, 22, 309-328. doi:10.1108/02683940710733115

Bakker, A.B., Demerouti, E., De Boer, E., \& Schaufeli, W. (2003). Job demands and job resources as predictors of absence duration and frequency. Journal of Vocational Behaviour, 62, 341-356. doi:10.1016/S0001-8791(02)00030-1

Bakker, A.B., Demerouti, E. \& Schaufeli, W.B. (2003). Dual processes at work in a call centre: An application of the Job Demands - Resources model. European Journal of Work and Organisational Psychology, 12, 393-417. doi:10.1080/13594320344000165

Bakker, A.B., Demerouti, E., \& Schaufeli, W.B. (2005). The crossover of burnout and work engagement among working couples. Human Relations, 58, 661-689. doi:10.1177/0018726705055967 
Bakker, A.B., Demerouti, E., Taris, T., Schaufeli, W. \& Schreurs, P. (2003). A multigroup analysis of the Job Demands-Resources Model in four home care organizations. International Journal of Stress Management, 10, 16-38. doi:10.1037/1072 5245.10.1.16

Bakker, A.B., Demerouti, E., \& Verbeke, W. (2004). Using the job demands-resources model to predict burnout and performance. Human Resource Management, 43, 83-104. doi:10.1002/hrm.20004

Bakker, A.B., Hakanen, J.J., Demerouti, E., \& Xanthopoulou, D. (2007). Job resources boost work engagement, particularly when job demands are high. Journal of Educational Psychology, 99, 274-284. doi:10.1037/0022-0663.99.2.274

Bakker, A.B., Van Emmerik, H., Van Riet, P., (2008). How job demands, resources, and burnout predict objective performance: A constructive replication. Anxiety, Stress, \& Coping, 21, 1-16. doi:10.1080/10615800801958637

Bentler, P.M. (1990). Comparative fit indexes in structural models. Psychological Bulletin 107, 238-246. doi:10.1037/0033-2909.107.2.238; PMid:2320703.

Berkowitz, L. (1989). The frustration-aggression hypothesis: An examination and reformulation. Psychological Bulletin, 106, 59-73. doi:10.1037/00332909.106.1.59, PMid:2667009

Bowling, N.A., \& Beehr, T.A. (2006). Workplace harassment from the victim's perspective: A theoretical model and meta-analysis. Journal of Applied Psychology 91, 998-1012. doi:10.1037/0021-9010.91.5.998, PMid:16953764

Brodsky, C.M. (1976). The harassed worker. Toronto: Lexington Books, D.C. Heath and Co.

Byrne, B.M. (2001). Structural Equation Modelling with Amos. Basic Concepts Application and Programming, Erlbaum, Mahwah, London (2001).

Cortina, J.M., Chen, G., \& Dunlap, W.P. (2001). Testing interaction effects in LISREL: Examination and illustration of available procedures.Organisational Research Methods, 4, 324-360. doi:10.1177/109442810144002

Cowie, H., Naylor, P., Smith, P.K., Rivers, I. \& Pereira, B. (2002). Measuring workplace bullying. Aggression and Violent Behaviour, 7, 35-51. doi:10.1016/S13591789(00)00034-3

De Cuyper, N., Baillien, E., \& De Witte, H. (2009). Job insecurity and workplace bullying among targets and perpetrators: moderation by employability. Work and Stress, 23, 206-224. doi:10.1080/02678370903257578

Demerouti, E., Bakker, A.B., Nachreiner, F., \& Schaufeli, W. (2001). The job demandsresources model of burnout. Journal of Applied Psychology, 86, 499-512. doi:10.1037/0021-9010.86.3.499

Einarsen, S. (2000). Harassment and bullying at work: a review of the Scandinavian approach. Agression and Violent Behaviour, 5, 379-401. doi:10.1016/\$13591789(98)00043-3

Einarsen, S., Matthiesen, S.B., \& Hauge, L.J. (2009). Bullying and harassment at work. In S. Cartwright \& C.L. Cooper (Eds.). The Oxford Handbook of Personne Psychology. (pp. 464 -495). London: Sage publications.

Einarsen, S., Raknes, B.I., \& Matthiesen, S.B. (1994). Bullying and harassment at work and their relationships to work environment quality: an exploratory study. European Work and Organisational Psychologist, 4, 381-401. doi:10.1080/13594329408410497

Einarsen, S., \& Skogstad, A. (1996). Bullying at work: Epidemiological findings in public and private organisations. European Journal of Work and Organisationa Psychology, 5, 185-201. doi:10.1080/13594329608414854

Felson, R.B, \& Tedeschi, J.T. (1993). Aggression and violence: Social interactionists' perspectives. Washington, DC: American Psychological Association. doi:10.1037/10123-000

González-Romá, V., Schaufeli, W.B., Bakker, A.B., \& Lloret, S. (2006). Burnout and work engagement: Independent factors or opposite poles? Journal of Vocational Behaviour, 68, 165-174. doi:10.1016/j.jvb.2005.01.003

Grant, A.M., \& Parker, S.K. (2009). Redesigning work design theories: The rise of relational and proactive perspectives. Academy of Management Annals, 3.

Hakanen, J., Bakker, A.B., \& Demerouti, E. (2005). How dentists cope with their job demands and stay engaged: the moderating role of job resources. European journal of Oral Sciences, 113, 479-487. doi:10.1111/j.1600-0722.2005.00250.x PMid:16324137

Hakanen, J., Bakker, A.B., \& Schaufeli, W.B. (2006). Burnout and work engagement among teachers. Journal of School Psychology, 43, 495-513. doi:10.1016/j. jsp.2005.11.001

Hakanen, J.J., Schaufeli, W.B., Ahola, K. (2008). The Job Demands-Resources model: A three-year cross-lagged study of burnout, depression, commitment, and work engagement. Work \& Stress, 22, 224-241. doi:10.1080/02678370802379432

Halbesleben, J.R.B., \& Buckley, M. R. (2004). Burnout in organisational life. Journal of Management, 30, 859-879. doi:10.1016/j.jm.2004.06.004

Hauge, L.J., Skogstad, A., \& Einarsen, S. (2007). Relationships between stressful work environments and bullying: Results of a large representative study. Work \& Stress, 21, 220-242. doi:10.1080/02678370701705810

Hinduja, S. (2007). Workplace violence and negative affective responses: A test of Agnew's general strain theory. Journal of Criminal Justice, 35, 657-666. doi:10.1016/j.jcrimjus.2007.09.002

Hobfoll, S.E. (2002). Social and psychological resources and adaptation. Review of General Psychology, 6, 307-324. doi:10.1037/1089-2680.6.4.307

Hoel, H., \& Salin, D. (2003). Organisational antecedents of bullying at work. In S. Einarsen, H. Hoel, D. Zapf \& C.L. Cooper (Eds.). Bullying and Emotional Abuse in the Workplace: International London: Taylor \& Francis.
Hoel, H., Zapf, D., \& Cooper, C.L. (2002). Bullying at work and stress. In P.L. Perrewe \& D.C. Ganster (Eds.). Historical and Current Perspectives on Stress and Health, 2 (pp. 293-333). Amsterdam: JAl. doi:10.1016/S1479-3555(02)02008-5

Holmbeck, G.N. (1997). Toward terminological, conceptual, and statistical clarity in the study of mediators and moderators: Examples from the child-clinical and pediatric psychology literatures. Journal of Consulting and Clinical Psychology, 65, 599-610. psychology literatures. Journal of Consulting and
doi:10.1037/0022-006X.65.4.599, PMid:9256561

Hoyle, R.H. (1995). The structural equation modeling approach: Basic concepts and fundamental issues. In R.H. Hoyle (Ed.), Structural equation modeling: Concepts, issues and applications (pp. 1-15). Thousand Oaks, CA: Sage.

Hu, L., \& Bentler, P.M. (1999). Cutoff criteria for fit indexes in covariance structure analysis: Conventional criteria versus new alternatives. Structural Equation Modeling, 6, 1-55. doi:10.1080/10705519909540118

Hubert, A., Furda, J. \& Steensma, H. (2001). Mobbing, systematisch pestgedrag in organisaties: Twee studies naar antecedenten en gevolgen voor de gezondheid Mobbing, systematic bullying in organisations: Two studies about antecedent and health related consequences]. Gedrag en Organisatie, 14, 378-369.

Jöreskog, K.G., \& Sörbom, D. (2004). LISREL 8.71 [Computer software]. Lincolnwood, IL: Scientific Software International, Inc

Karasek, R. (1979). Job demands, job decision latitude, and mental strain Implications for job redesign. Administrative Science Quarterly, 24, 285-308. Implications for job rede
doi:10.2307/2392498

Keashly, L. (1998). Emotional abuse in the workplace: conceptual and empirical issues. Journal of Emotional Abuse, 1, 85-117. doi:10.1300/J135v01n01_05

Kristensen, T. S., Hannerz, H., Hogh, A., \& Borg, V. (2005). The Copenhagen Psychosocial Questionnaire: A tool for the assessment and improvement of the psychosocial work environment Scandinavian Journal of Work Environment \& Health, 31, 438-449. PMid:16425585

Leymann, H. (1996). The content and development of mobbing at work European Journal of Work and Organisational Psychology, 5, 165-184. doi:10.1080/13594329608414853

Llorens, S., Schaufeli, W.B., Bakker, A.B, Schaufeli, W.B. \& Salanova, M. (2006). Testing the robustness of the Job Demands-Resources Model International Journal of Stress Management, 13,378-391. doi:10.1037/1072-5245.13.3.378

Martinussen, M., Richardsen, A.M. \& Burke, R.J. (2007). Job demands, job resources, and burnout among police officers, Journal of Criminal Justice, 35, 239-249. doi:10.1016/j.jcrimjus.2007.03.001

Maslach, C., Schaufeli, W., \& Leiter, M. (2001). Job burnout. Annual Review of Psychology, 52, 397-422. doi:10.1146/annurev.psych.52.1.397, PMid:11148311

Mathieu, J.E., Tannenbaum, S.I., \& Salas, E. (1992). Influences of individual and situational characteristics on measures of training effectiveness. Academy of Management Journal, 35, 828-847. doi:10.2307/256317

Matthiesen, S.B., \& Einarsen, S. (2007). Perpetrators and targets of bullying at work: role stress and individual differences. Violence and Victim, 22, 735-753. doi:10.1891/088667007782793174, PMid:18225386

Meier, L.L. (2008). IRSE. Interactions in Multiple Linear Regression with SPSS and Exce (Version 1.6) [Computer software and manual]. Retrieved November 22, 2009, from $h$ ttp://www.urenz.ch/irse

Mikkelsen, E.G. \& Einarsen, S. (2002). Bullying in Danish work-life: Prevalence and health correlates. European Journal of Work and Organisational Psychology, 10(4), 393-413. doi:10.1080/13594320143000816

Neyens, I., Baillien, E., Notelaers, G., \& De Witte, H. (2007). Pesten op het werk: Risicofactoren in werk en organisatie [Workplace bullying: Risk factors in the job and the organisation]. Tijdschrift voor Arbeidsvraagstukken, 23, 306-320.

Nielsen, M.B., Skogstad, A., Matthiesen, S.B., Glaso, L., Aasland, M.S., Notelaers, G. $\&$ Einarsen, S. (2009). Prevalence of workplace bullying in Norway: Comparisons across time and estimation methods. European Journal of Work and Organisational Psychology, 18, 81-101. doi:10.1080/13594320801969707

Notelaers, G., \& Einarsen, S. (2008). The construction and validation of the Short Negative Acts Questionnaire. Paper presented at 6th International Conference on Workplace Bullying. Montreal, Canada.

Notelaers, G., De Witte, H. \& Einarsen, S. (2010). A job characteristics approach to explain workplace bullying. European Journal of Work and Organisationa to explain workplace bullying. European Journal of Work
Psychology, 19, 487-504. doi: 10.1080/13594320903007620

Parkins, I.S., Fishbein, H.D., \& Ritchey, P.N. (2006). The influence of personality on workplace bullying and discrimination. Journal of Applied Psychology, 36, 2554-2577. doi:10.1111/j.0021-9029.2006.00117.x

Podsakoff, N.P., LePine, J.A., LePine, M.A. (2007). Differential challenge stressorhindrance stressor relationships with job attitudes, turnover intentions, turnover and withdrawal behavior: A meta-analysis. Journal of Applied Psychology, 92, 438-454.

Podsakoff, P.M., MacKenzie, S.B., Lee, J.-Y, \& Podsakoff, N.P. (2003). Common method biases in behavioural research: A critical review of the literature and recommended remedies. Journal of Applied Psychology, 88, 879-903. doi:10.1037/0021 9010.92.2.438, PMid:17371090

Rayner, C. (1999). From research to implementation: finding leverage for prevention. International Journal of Manpower, 20, 28-38. doi:10.1108/01437729910268614

Rigotti, T., Mohr, G., Cuyper, N. De, Witte, H. De, Bernhard, C., Isaksson, K., Jong, J. de, Schalk, R., Caballer, A., Gracia, F., Peiró, J.M., Ramos, J., Clinton, M., Guest, D., Krausz, M. \& Staynvarts, N. (2003). Instruction work and blue print for methodology. Unpublished research report. Leipzig: Germany.

Rodell, J.B., \& Judge, T.A., (2009). Can "Good" Stressors Spark "Bad" Behaviors? The Mediating Role of Emotions in Links of Challenge and Hindrance Stressors With Citizenship and Counterproductive Behaviors. Journal of Applied Psychology, 94, 1438-1451. doi:10.1037/a0016752, PMid:19916654 
Rodriguez-Muños, A., Baillien, E., De Witte, H., Moreno-Jiménez, B., \& Pastor, J.C (2009). Cross-lagged relationships between workplace bullying, job satisfaction and engagement: Two longitudinal

Rosenthal, P., Guest, D., \& Peccei, R. (1996). Gender difference in managers' explanation for their work performance: A study in two organisations. Journal of Occupational and Organisational Psychology, 69, 145-151.

Rousseau, D.M., \& Fried, Y. (2001). Location, location, location: contextualizing organisational research. Journal of Organisational Behaviour, 22, 1-13. doi:10.1002/job.78

Salanova, M., Agut, S., \& Peiró, J. (2005). Linking organisational resources and work engagement to employee performance and customer loyalty: The mediation of service climate. Journal of Applied Psychology, 90, 1217-1227. doi:10.1037/0021 9010.90.6.1217, PMid:16316275

Salin, D. (2003). Ways of explaining workplace bullying: A review of enabling, motivating and precipitating structures and processes in the work environment Human Relations, 56, 1213-1232. doi:10.1177/00187267035610003

Salin, D. (2008). The prevention of workplace bullying as a question of human resource management: Measures adopted and underlying organisational factors. Scandinavian Journal of Management, 24, 221-231. doi:10.1016/j. factors. Scandinavian

Satorra, A., \& Bentler, P.M. (1994). Corrections to test statistics and standard errors in covariance structure analysis. In A. von Eye \& C.C. Clogg (Eds.), Latent variables analysis: Applications for developmental research (pp. 399-419). Thousand Oaks, CA: Sage.

Schaufeli, W.B., \& Bakker, A.B. (2004). Job demands, job resources, and their relationship with burnout and engagement: a multi-sample study. Journal of Organisational Behaviour, 25, 293-315. doi:10.1002/job.248

Schaufeli, W.B., \& Van Dierendonck, D. (2000) Utrechtse Burnout Schaal (UBOS): Testhandleiding. Amsterdam: Harcourt Test Services.

Siegrist, J. (1996). Adverse health effects of high effort-low reward conditions. Journa of Occupational Health Psychology, 1, 27-41. doi:10.1037/1076-8998.1.1.27 PMid:9547031
Van den Broeck, A., Vansteenkiste, M., De Witte H., \& Lens, W. (2008). Explaining the relationships between job characteristics, burnout and engagement: The role of basic psychological need satisfaction. Work \& Stress, 22, 277-294. role of basic psychological need

Van den Broeck, A., Vansteenkiste, M., De Cuyper, N., \& De Witte, H. (2010). Not all Job Demands are Created Equal: Differentiating Job Hindrances and Job Challenges in the Job Demands-Resources Model. European Journal of Work and Organizational Psychology,19, 735-759. doi: 10.1080/13594320903223839

Van Veldhoven, M., \& Meyman, T.F. (1994). Het meten van psychosociale arbeidsbelasting met een vragenlijst: de vragenlijst beleving en beoordeling van de arbeid (VBBA) [Measuring psychosocial demands with a questionnaire: the VBBA]. Amsterdam: NIA.

Williams, L.J., Cote, J.A., \& Buckley, M.R. (1989). Lack of method variance in selfreported affect and perceptions of work: Reality or artifact? Journal of Applied Psychology, 74, 462-468. doi:10.1037/0021-9010.74.3.462

Xanthopoulou, D., Bakker, A.B., Demerouti, E., \& Schaufeli, W.B. (2009). Work engagement and financial returns: A diary study on the role of job and personal resources. Journal of Organisational and Occupational Psychology, 82, 183-200. doi:10.1348/096317908X285633

Zapf, D. (1999). Organisational, work group related and personal causes of mobbing/bullying at work. International Journal of Manpower, 20, 70-85. doi:10.1108/01437729910268669

Zapf, D., \& Einarsen, S. (2003). Individual antecedents of bullying: victims and perpetrators. In S. Einarsen, H. Hoel, D. Zapf, \& C.L. Cooper (Eds.). Bullying and Emotional Abuse in the Workplace. International Perspectives in Research and Practice (pp.165-184). London: Taylor \& Francis.

Zapf, D., \& Gross, C. (2001). Conflict escalation and coping with workplace bullying: A replication and extension. European Journal of Work and Organisationa Psychology, 10, 497-522. doi:10.1080/13594320143000834

Zapf, D., Knorz, C., \& Kulla, M. (1996). On the relationship between mobbing factors, and job content, social work environment, and health outcomes. European Journal of Work and Organisational Psychology, 5, 215-237. European Journal of Work and 